\title{
SHORT-TERM OUTCOME OF MASSIVE PULMONARY HEMORRHAGE IN PRETERM INFANTS IN TUZLA CANTON
}

\author{
Devleta Hadžić, Evlijana Zulić, Sabina Salkanović-Delibegović, Dženana Softić, \\ Dženita Kovačević and Delila Softić
}

Department of Pediatrics, Tuzla University Clinical Centre, Tuzla, Bosnia and Herzegovina

\begin{abstract}
SUMMARY - Massive pulmonary hemorrhage (MPH) in neonates is a severe condition followed by many complications and associated with a high mortality rate. The aim of this study was to present the incidence, possible risk factors, and short-term outcome of neonatal MPH in Tuzla Canton. We retrospectively analyzed data on neonates with MPH from January 2015 to December 2017. On statistical analysis, standard methods of descriptive statistics were used. During the three-year study period, 16 neonates developed MPH, 5 (31.25\%) male and $11(68.75 \%)$ female. Their mean gestational age was $29.48 \pm 2.21$ weeks and mean birth weight $1276.69 \pm 387.65$ grams. Seven $(43.75 \%)$ neonates survived and $9(56.25 \%)$ died. Significant differences between the two outcome groups (survivors/died) were found in gestational age, birth weight, birth length, 5-minute Apgar score, and length of treatment at the Neonatal Intensive Care Unit. In Tuzla Canton, MPH occurred mainly in preterm neonates requiring mechanical ventilation, with the incidence of $1.91 \%$ of total premature births. The short-term outcome was uncertain, with a high mortality rate of $56.25 \%$. Lower gestational age, lower birth weight, lower birth length and lower 5-minute Apgar score were confirmed as risk factors for poor short-term outcome.
\end{abstract}

Key words: Massive pulmonary hemorrhage; Neonates, prematurity; Short-term outcome; Risk factors

\section{Introduction}

Massive pulmonary hemorrhage (MPH) in neonates is a severe condition that is characterized by the presence of hemorrhagic fluid in the trachea accompanied by respiratory decompensation. The short-term outcome could be dramatic and uncertain, followed by many complications, and with a high mortality rate. The exact pathogenesis is not known yet, but there are many factors that can contribute and lead to the development of MPH. Older papers have reported MPH in both preterm and full-term neonates, with a higher mortality rate in preterm infants, and usually related to

Correspondence to: Assist. Prof. Devleta Hadžic, $M D, P h D$, Department of Pediatrics, Tuzla University Clinical Centre, Prof. dr. Ibre Pašića bb, 75000 Tuzla, Bosnia and Hercegovina

E-mail: devletahadzic@yahoo.com

Received December 4, 2018, accepted October 2, 2019 perinatal asphyxia, surfactant deficiency, and some serious illnesses ${ }^{1}$. Currently, it is more often described in preterm ventilated neonates, with different incidence reports ${ }^{1-3}$. Typical presentation is dramatic and rapid deterioration that starts with reddish foamy discharge in the endotracheal tube or mouth. It is followed by hypotonia, bradycardia, apnea, pallor, and increased need for oxygen. Chest x-rays are usually nonspecific, as it may appear as fluffy opacities, focal ground-glass opacities or complete white-out lungs in widespread MPH. There are still no proper recommendations for treatment ${ }^{4,5}$. Even though surfactant usage is mentioned as a precipitating factor for $\mathrm{MPH}$ development $^{1}$, various studies show that surfactant therapy should be suggested for treatment of this disorder ${ }^{6-8}$. Also reportedly maternal prophylaxis with antenatal glucocorticoids is associated with a reduced risk of pulmonary hemorrhage ${ }^{9}$. Regarding prognosis, there 
are controversial data on further development; some studies showed no impact ${ }^{10}$, whereas others demonstrated it to carry an increased risk of neurodevelopmental disorders ${ }^{11}$. Regarding short-term outcome, studies report a mortality rate of $40 \%$ to $60 \%^{2,8,10}$.

The aim of this study was to assess the incidence, possible risk factors, and short-term outcome of neonatal MPH in Tuzla Canton.

\section{Patients and Methods}

In a retrospective observational study, medical records of all neonates admitted to the Neonatal Intensive Care Unit (NICU), Department of Pediatrics, Tuzla University Clinical Center, during a three-year period (from January 2015 to December 2017), a total of 604 patients were screened, and we reviewed records of the neonates with observed and treated MPH; finally, data on 16 neonates were included in the study.

Patients were evaluated for baseline characteristics, predisposing factors for MPH, accompanying disorders, and mortality. We reviewed data on patient demographics including gestational age, birth weight, gender, and Apgar scores at the $1^{\text {st }}$ and $5^{\text {th }}$ minute, type of delivery, possible premature rupture of membrane, postnatal age at the time of NICU admission, time to manifest MPH, and inborn-outborn status. Characteristics of the neonates admitted with MPH $(\mathrm{N}=16)$ are shown in Table 1.

Previous lung health was analyzed through initial radiographic lung findings obtained before MPH development. We analyzed laboratory, microbiological and radiological findings, therapeutic procedures, length of NICU stay, and outcome. The study was approved by the institutional review board (Ethics Committee). Statistical analysis was performed by use of standard methods of descriptive statistics. The significance of differences between the groups was tested by parametric and nonparametric tests of significance and methods of linear correlation using statistical Arcus Quick Stat and Systat software.

\section{Results}

From January 2015 to the end of December 2017, there were 11,425 neonates including 10,588 full-term and 837 preterm (625 late preterm and 212 very preterm) in Tuzla Canton, with a $7.33 \%$ preterm birth
Table 1. Clinical characteristics of neonates with massive pulmonary hemorrhage

\begin{tabular}{|c|c|c|c|}
\hline Gender (n) & Male/Female & \multicolumn{2}{|l|}{$5 / 11$} \\
\hline $\begin{array}{l}\text { Delivery } \\
\text { characteristic }\end{array}$ & $\mathrm{n}$ & \multicolumn{2}{|l|}{$\%$} \\
\hline $\begin{array}{l}\text { Cesarean } \\
\text { section }\end{array}$ & 10 & \multicolumn{2}{|l|}{62.5} \\
\hline Inborn & 15 & \multicolumn{2}{|l|}{93.75} \\
\hline Outborn & 1 & \multicolumn{2}{|l|}{6.25} \\
\hline $\begin{array}{l}\text { Risky maternal } \\
\text { disease }\end{array}$ & 11 & \multicolumn{2}{|l|}{68.75} \\
\hline $\begin{array}{l}\text { Antenatal } \\
\text { corticosteroids }\end{array}$ & 10 & \multicolumn{2}{|l|}{62.5} \\
\hline & $\chi \pm S D$ & Minimum & Maximum \\
\hline $\begin{array}{l}\text { Birth weight } \\
\text { (g) }\end{array}$ & $1276.7 \pm 387.7$ & 850.0 & 1970.0 \\
\hline $\begin{array}{l}\text { Birth length } \\
(\mathrm{cm})\end{array}$ & $39.2 \pm 5.2$ & 28.0 & 47.0 \\
\hline $\begin{array}{l}\text { Gestational age } \\
\text { (weeks) }\end{array}$ & $29.4 \pm 2.2$ & 27 & 34 \\
\hline $\begin{array}{l}\text { Apgar score } \\
1^{\text {st minute }}\end{array}$ & $4.75 \pm 2.5$ & 1 & 8 \\
\hline $\begin{array}{l}\text { Apgar score } \\
5^{\text {th }} \text { minute }\end{array}$ & $5.7 \pm 1.2$ & 3 & 8 \\
\hline $\begin{array}{l}\text { Postnatal age } \\
\text { at MPH } \\
\text { occurrence } \\
\text { (days) }\end{array}$ & $7.4 \pm 6$ & 2 & 25 \\
\hline $\begin{array}{l}\text { Duration of } \\
\text { MV (days) }\end{array}$ & $9.7 \pm 9$ & 3 & 30 \\
\hline $\begin{array}{l}\text { NICU length } \\
\text { of stay (days) }\end{array}$ & $25.1 \pm 26.1$ & 2 & 83 \\
\hline
\end{tabular}

$\chi \pm \mathrm{SD}=$ mean \pm standard deviation; $\mathrm{MPH}=$ massive pulmonary hemorrhage; $\mathrm{MV}=$ mechanical ventilation; $\mathrm{NICU}=$ neonatal intensive care unit

rate. In total, 604 neonates were admitted to the NICU, including 237 term and 367 premature (172 late premature and 195 very preterm), and 265 neonates (215 premature and 50 term) required mechanical ventilation. During the three-year study period, 16 premature neonates developed MPH, yielding the incidence of $1.91 \%$ of the total number of premature births, $4.35 \%$ of the total number of premature infants who were treated in the NICU and $7.44 \%$ of those requiring mechanical ventilation. According to gender distribution, there were $5(31.25 \%)$ male and 11 $(68.75 \%)$ female infants. 
Table 2. Comorbidity in neonates with massive pulmonary hemorrhage

\begin{tabular}{|c|c|c|c|c|}
\hline Condition & $\begin{array}{l}\text { Moderate preterm } \\
(32-34 \text { GW) } \\
n=2\end{array}$ & $\begin{array}{l}\text { Very preterm } \\
(<32 \mathrm{GW}) \mathrm{n}=14\end{array}$ & $\begin{array}{l}\text { Extremely preterm } \\
(<28 \mathrm{GW}) \mathrm{n}=4\end{array}$ & Total $(\mathrm{N}=16)$ \\
\hline $\begin{array}{l}\text { Respiratory distress syndrome } \\
\text { (hyposurfactosis) }\end{array}$ & 2 & 14 & 4 & 16 \\
\hline Perinatal asphyxia & 1 & 8 & 2 & 9 \\
\hline $\begin{array}{l}\text { Intracranial hemorrhage mild } \\
\text { to moderate }\end{array}$ & 2 & 6 & 1 & 8 \\
\hline $\begin{array}{l}\text { Intracranial hemorrhage moderate } \\
\text { to severe }\end{array}$ & - & 8 & 3 & 8 \\
\hline Pneumonia & 1 & 9 & 1 & 10 \\
\hline Atelectasis & 1 & 9 & 2 & 10 \\
\hline Pneumothorax & - & 2 & 1 & 2 \\
\hline Sepsis & 1 & 8 & 3 & 9 \\
\hline
\end{tabular}

$\mathrm{GW}=$ gestational weeks

Table 3. Baseline laboratory findings in neonates with massive pulmonary hemorrhage

\begin{tabular}{|l|l|l|l|}
\hline Parameter & $\chi \pm \mathrm{SD}$ & Minimum & Maximum \\
\hline C-reactive protein $(\mathrm{mg} / \mathrm{L})$ & $22.22 \pm 51.32$ & 1.6 & 205.3 \\
White blood cell count $\left(\mathrm{x} 10^{9} / \mathrm{L}\right)$ & $8.29 \pm 3.92$ & 2.6 & 15.4 \\
Absolute neutrophil count & $5838.5 \pm 4533.8$ & 567 & 9108 \\
Hematocrit $(\mathrm{L} / \mathrm{L})$ & $0.524 \pm 0.1$ & 0.37 & 0.72 \\
Hemoglobin $(\mathrm{g} / \mathrm{L})$ & $183.0 \pm 5.7$ & 124.0 & 252.0 \\
Erythrocytes $\left(\mathrm{x} 10^{12} / \mathrm{L}\right)$ & $4.7 \pm 0.9$ & 3.8 & 6.8 \\
Platelets $\left(x 10^{9} / \mathrm{L}\right)$ & $165.2 \pm 0.9$ & 53 & 300 \\
\hline Prothrombin time (INR) & $1.216250 \pm 0.14$ & 1.0 & 1.4 \\
Activated partial thromboplastin time & $51.41 \pm 3.88$ & 45.3 & 56.4 \\
Thrombin time & $23.25 \pm 2.3$ & 20 & 28.5 \\
Fibrinogen $(\mathrm{g} / \mathrm{L})$ & $2.41 \pm 0.67$ & 1.4 & 3.8 \\
\hline
\end{tabular}

$\chi \pm \mathrm{SD}=$ mean \pm standard deviation; INR = International Normalized Ratio

The mean gestational age was $29.48 \pm 2.21$ weeks. All neonates with $\mathrm{MPH}$ were premature infants aged under 35 gestational weeks $(\mathrm{GW})$. Two of them were moderate preterm (32-34 GW), 14 were very preterm $(<32 \mathrm{GW})$, and 4 were extremely preterm $(<28 \mathrm{GW})$. The mean birth weight was $1276.69 \pm 387.65 \mathrm{~g}$. All of them were low birth weight $(<2500 \mathrm{~g}), 12(75 \%)$ were very low birth weight $(<1500 \mathrm{~g})$ and 4 were extremely low birth weight $(<1000 \mathrm{~g})$.

Among the 16 neonates with $\mathrm{MPH}$, the most commonly associated diseases were respiratory distress syndrome, perinatal asphyxia, intracranial hemorrhage, pneumonia, and sepsis (Table 2). Baseline laboratory findings in the observed neonates are shown in Table 3. Laboratory parameters of inflammatory markers and coagulation status in neonates with MPH did not show significant difference in comparison to those without MPH, and 6 of the 9 neonates with sepsis had microbiological confirmation of the diagnosis. The most commonly isolated pathogens were coagulase negative Staphylococcus, Enterococcus sp. and Acinetobacter. Previous lung condition recorded on chest radi- 
Table 4. Abnormal laboratory findings in neonates with massive pulmonary hemorrhage

\begin{tabular}{|l|l|l|l|l|}
\hline Parameter & Total, $\mathrm{n}$ & Survivors & Non-survivors & $\mathrm{p}$ value \\
\hline C-reactive protein $<5 \mathrm{mg} / \mathrm{L}$ & 10 & $5 / 7$ & $5 / 9$ & 0.5152 \\
C-reactive protein $>10 \mathrm{mg} / \mathrm{L}$ & 6 & $2 / 7$ & $4 / 9$ & 0.7710 \\
White blood cell count $<6 \times 10^{9} / \mathrm{L}$ & 7 & $4 / 7$ & $3 / 9$ & 0.3409 \\
White blood cell count $>13 \times 10^{9} / \mathrm{L}$ & 5 & $3 / 7$ & $2 / 9$ & 0.3770 \\
Hematocrit $<0.45$ & $4 / 16$ & $2 / 7$ & $2 / 9$ & 0.7711 \\
Hematocrit $>0.65$ & $2 / 16$ & $1 / 7$ & $1 / 9$ & 0.8489 \\
Platelets $<150 \times 10^{9} / \mathrm{L}$ & $8 / 16$ & $2 / 7$ & $6 / 9$ & 0.1306 \\
Coagulation disorders & $4 / 16$ & $2 / 7$ & $2 / 9$ & 0.7711 \\
\hline
\end{tabular}

Table 5. Mortality (short-term outcome risk factors for massive pulmonary hemorrhage)

\begin{tabular}{|c|c|c|c|}
\hline Parameter & Survivors & Non-survivors & $\mathrm{p}$ value \\
\hline $\mathrm{n}$ & $7 / 16$ & $9 / 16$ & 0.4795 \\
\hline Male & $2 / 7$ & $3 / 9$ & 0.8384 \\
\hline Gestational age (weeks), $\chi \pm \mathrm{SD}$ (min-max) & $\begin{array}{l}30.57 \pm 2.37 \\
(27-34)\end{array}$ & $\begin{array}{l}28.44 \pm 1.66 \\
(26-31)\end{array}$ & 0.05 \\
\hline Birth weight $(\mathrm{g}), \chi \pm \mathrm{SD}$ (min-max) & $\begin{array}{l}1547.14 \pm 435.61 \\
(1000-1970)\end{array}$ & $\begin{array}{l}1066.33 \pm 160.21 \\
(850-1300)\end{array}$ & 0.0082 \\
\hline$<1500 \mathrm{~g}$ & $3 / 7$ & $9 / 9$ & 0.0088 \\
\hline$>1500 \mathrm{~g}$ & $4 / 7$ & $0 / 9$ & 0.0088 \\
\hline Birth length $(\mathrm{cm}), \chi \pm \mathrm{SD}(\min -\max )$ & $43.0 \pm 1.41(37-47)$ & $\begin{array}{l}36.22 \pm 3.46 \\
(32-44)\end{array}$ & 0.045 \\
\hline 1-minute Apgar score, $\chi \pm \mathrm{SD}(\min -\max )$ & $\begin{array}{l}6.0 \pm 4.58 \\
(3-7)\end{array}$ & $\begin{array}{l}3.78 \pm 2.73 \\
(1-8)\end{array}$ & 0.0714 \\
\hline 5-minute Apgar score, $\chi \pm \mathrm{SD}(\min -\max )$ & $\begin{array}{l}6.86 \pm 1.067 \\
(5-8)\end{array}$ & $\begin{array}{l}4.78 \pm 2.11 \\
(3-8)\end{array}$ & 0.0327 \\
\hline Postnatal age at MPH occurrence (days) & $\begin{array}{l}7.29 \pm 4.75 \\
(2-15)\end{array}$ & $\begin{array}{l}7.44 \pm 7.07 \\
(2-25)\end{array}$ & 0.9601 \\
\hline Length of MV (days) & $\begin{array}{l}13.43 \pm 9.74 \\
(3-30)\end{array}$ & $\begin{array}{l}6.78 \pm 7.64 \\
(1-26)\end{array}$ & 0.1475 \\
\hline Surfactant replacement therapy & $17 / 7$ & $18 / 9$ & 1.0 \\
\hline Length of NICU treatment (days) & $\begin{array}{l}47.43 \pm 24.42 \\
(13-83)\end{array}$ & $\begin{array}{l}7.78 \pm 7.31 \\
(2-26)\end{array}$ & 0.0004 \\
\hline
\end{tabular}

$\chi \pm \mathrm{SD}=$ mean \pm standard deviation; $\mathrm{MPH}=$ massive pulmonary hemorrhage; $\mathrm{MV}=$ mechanical ventilation; $\mathrm{NICU}=\mathrm{Neonatal}$ Intensive Care Unit

ography (chest x-ray) before the onset of MPH generally described moderate or severe degree of respiratory distress syndrome and pneumonia in 10 neonates, bilateral in 7 of them. Chest radiography after $\mathrm{MPH}$ was described in survivors as progression of infiltration and atelectasis, unilateral or bilateral.

In all cases, the diagnosis was based on clinical manifestation of sudden appearance of bloody fluid from the mouth, nose, or endotracheal tube, with related worsening of the respiratory and cardiovascular function to the state of severe shock. Actually, in all cases, it was a very urgent state of life endangerment, which required urgent action for treatment and resuscitation. Emergency treatment included standard resuscitation procedures (aspiration, re-intubation, airway cleaning procedures) with simultaneous adminis- 
tration of crystalloids, colloids, blood products and medications. Epinephrine via endotracheal route was applied in all cases, and in 4 cases a surfactant was administered shortly after MPH onset. All patients required correction parameters on mechanical ventilation and demanded reinforcing respiratory support. The length of mechanical ventilation was 3-30 (9.7 \pm 9$)$ days and of NICU stay 3-84 (25.0 26.1$)$ days.

In conclusion, as for the short-term outcome, 7 (43.75\%) MPH neonates survived, whereas 9 (56.25\%) MPH neonates died. All perinatal risk factors were analyzed in the two groups of neonates with MPH divided according to outcome (survivors/died). There were no significant differences in baseline laboratory findings between the two groups of MPH neonates according to outcome (Table 4). Significant differences between the two groups were found in gestational age, birth weight, birth length, 5-minute Apgar score, and length of NICU treatment (Table 5). All these parameters were worse in the group of non-survivors, except for the length of NICU treatment, which was significantly longer in survivors.

\section{Discussion}

Massive pulmonary hemorrhage is a life-threatening condition that, according to current literature, complicates hospital course in 3\%-5\% of preterm infants and generally occurs in 1-12 per 1000 live births, with the rate increasing to 50 per 1000 live births in the groups at risk such as prematurity and severe illnesses ${ }^{1-3}$. In our region, we found the incidence of MPH to be $1.91 \%$ of total premature births, $4.35 \%$ of NICU treated preterm neonates, and $7.44 \%$ of those requiring mechanical ventilation. Gender distribution usually shows a slight predominance of female infants ${ }^{2}$, as also recorded in our study. As for gestational age, all neonates with MPH in our study were premature infants, nearly all (87.5\%) were very preterm neonates $(<32 \mathrm{GW})$, and a quarter of all were extremely immature $(<28 \mathrm{GW})$. Very similar results were obtained for the birth weight parameter because all MPH neonates in our study were low birth weight $(<2500 \mathrm{~g})$, nearly all $(75 \%)$ were very low birth weight $(<1500 \mathrm{~g})$, and a quarter of all were extremely low birth weight $(<1000$ g). In studies from the 1990s, MPH occurred in both preterm and full-term neonates, however, in preterm infants it developed later and was associated with a higher mortality rate than in full-term infants ${ }^{11,12}$. Recent major studies have just highlighted lower gestational age and lower birth weight as the strongest risk factors for the development of $\mathrm{MPH}^{2,3}$.

The exact pathogenesis of MPH remains unknown, however, there are many factors that can contribute and lead to the development of MPH. It is related to perinatal asphyxia, surfactant deficiency, hypothermia, septicemia, pneumonia, coagulation disorders, congenital heart disease, maternal blood aspiration, intravenous administration of hyperosmolar solutions, and diffuse pulmonary embolism with drug micro-aggregates $^{1}$. In our study, the most commonly associated diseases in neonates with MPH were respiratory distress syndrome, perinatal asphyxia, intracranial hemorrhage, pneumonia and sepsis, which is consistent with literature data, possibly better with the older one ${ }^{11}$. Because most of the patients suffered from perinatal asphyxia, it was assumed that left ventricular failure with subsequent increase in pulmonary capillary pressure was one of the main precipitating factors. In their study, West et al. ${ }^{12}$ suggest that stress failure of pulmonary capillaries due to alveolar overdistention and high pulmonary capillary pressure, which causes leakage of hemorrhagic edema fluid into air spaces, is one of the most likely mechanisms of MPH development. Pulmonary hemorrhage occurs mainly in ventilated preterm infants with severe respiratory distress syndrome who have received surfactant therapy ${ }^{13}$. There is evidence that surfactant impairs coagulation in vitro, and therefore it is seriously considered as a risk factor for pulmonary hemorrhage ${ }^{14}$. Some authors suggest that the use of a surfactant can lead to rapid lowering of intrapulmonary pressure and consequential increase in pulmonary blood flow by facilitating left to right shunting across patent ductus arteriosus (PDA), which can cause pulmonary hemorrhage $e^{6-8}$. We did not find significant differences in surfactant treatment between surviving neonates with $\mathrm{MPH}$ compared to those who did not survive. We did not find any significant differences in coagulation status either.

In emergencies such as life-threatening $\mathrm{MPH}$, it is essential to have consistent recommendations for effective treatment, which unfortunately, has not been reached yet. Different approaches have been proposed including high airway pressures during mechanical ventilation, high frequency oscillation ventilation (HFOV), extracorporeal membrane oxygenation 
(ECMO), administration of recombinant activated factor VII, and surfactant replacement therapy ${ }^{5-8}$. Certainly, it is very important how we treat respiratory failure. Mechanical ventilation in neonates is still a more complex area, the safety and successful application of which requires good knowledge of pulmonary physiology and pathophysiology that is changing with age, and ventilation should be designed according to the age, lung disease characteristics and pathophysiological process causing respiratory insufficiency. Currently, there are many options, strategies and modalities, suggesting that we have not created an ideal mode yet, which would maximally respond to the needs of a child and expedite recovery with minimal complications ${ }^{15}$. MPH has been effectively treated with surfactant instillation, even in those neonates who have already received this before ${ }^{6-8}$. Pandit et al. ${ }^{10}$ noted improvement of the oxygen index when they used a surfactant in 15 neonates with MPH. Amizuka et al. ${ }^{6}$ used a surfactant in 26 of 27 neonates with MPH, with good response in $82 \%$ of cases at one hour after surfactant administration. Grizelj et al..$^{5}$ used activated factor VII to provide maximum activation of the coagulation system localized to the site of injury, and recommend it as a safe additional life-saving therapeutic option for neonates experiencing life-threatening MPH. Suryawanshi et al. ${ }^{8}$ promote treatment for neonatal MPH, almost identical to that in our institution, which includes epinephrine via endotracheal tube, avoiding unnecessary endotracheal suction, blood products, and correction of treatment for secondary respiratory distress syndrome by appropriate and best respiratory support, with or without repeat surfactant.

Prevention could be more effective than treatment. Could MPH be predicted or prevented, and could risk factors for poor short-term outcome be recognized earlier? Reportedly maternal prophylaxis with antenatal glucocorticoids is associated with a reduced risk of pulmonary hemorrhage 9 . We did not find significant differences in the maternal risk factors or use of antenatal corticosteroid prophylaxis between surviving neonates with $\mathrm{MPH}$ compared to those who did not survive. We did not find significant difference in baseline laboratory findings either. Significant differences between the two groups were recorded in gestational age, birth weight, birth length, 5-minute Apgar score, and length of NICU treatment. Most studies report a similar mortality rate for MPH and similar risk factors for poor outcome, although in our study we did not find any significance regarding maternal risk factors, antenatal corticosteroid prophylaxis, or surfactant treatment. Usually, birth weight discordance is reported as a risk factor for adverse perinatal outcomes ${ }^{16}$. It is interesting that in our research, the mean birth length was significantly lower in the group of non-survivors as compared to survivors. For comparison, there is almost no study that considered birth length at all. The length of NICU treatment was significantly longer in survivors ( $47.42 \pm 24.41$ days) versus those with lethal outcome $(7.45 \pm 7.07$ days).

\section{Conclusion}

Because of its outstanding severity and high mortality rates, neonatal MPH deserves great attention of all, and not only those who provide intensive care for premature neonates. In Tuzla Canton, MPH occurred mainly in preterm neonates and those requiring mechanical ventilation due to respiratory distress syndrome. The incidence of MPH was $1.91 \%$ of total premature births, $4.35 \%$ of NICU treated preterm neonates, and $7.44 \%$ of those requiring mechanical ventilation. The short-term outcome was uncertain, i.e. favorable in $43.75 \%$ of survivors, while the mortality rate was high $(56.25 \%)$. We did not find significant difference regarding maternal risk factors, antenatal corticosteroid prophylaxis, or surfactant treatment between surviving neonates with MPH and non-survivors. Lower gestational age, lower birth weight, lower birth length, and lower 5-minute Apgar score were confirmed as the risk factors for poor short-term outcome in neonates with MPH.

\section{References}

1. Papworth S, Cartlidge PHT. Pulmonary haemorrhage. Curr Paediatr. 2001;11:167-71.doi.org/10.1054/cupe.2000.0175

2. Ferreira $\mathrm{CH}$, Carmona F, Martinez FE. Prevalence, risk factors and outcomes associated with pulmonary hemorrhage in newborns. J Pediatr (Rio J). 2014;90:316-22. doi.org/10.1016/j. jped.2013.12.008

3. Berger TM, Allred EN, Van Marter LJ. Pulmonary hemorrhage in very low-birth weight infants: risk factors and management. Chen YY, Taiwan Premature Infant Development Collaborative Study Group. Pediatr Int. 2012;54(6):743-7. doi: 10.7860/JCDR/2015/8596.5691 
4. Kolovos NS, Schuerer DJ, Moler FW, Bratton SL, Swaniker F, Bartlet RH, et al. Extracorporeal life support for pulmonary hemorrhage in children: a case series. Crit Care Med. 2002; 30:577-80. doi:10.1097/00003246-200203000-00014

5. Grizelj R, Vukovic J, Filipovic-Grcic B, Saric D, Luetic T. Successful use of recombinant activated FVII and aminocaproic acid in four neonates with life-threatening hemorrhage. Blood Coagul Fibrinolysis. 2006;17:413-5. doi: 10.1097/01.mbc.000 0233373.71970.6f

6. Amizuka T, Shimizu H, Niida Y, Ogawa Y. Surfactant therapy in neonates with respiratory failure due to haemorrhagic pulmonary oedema. Eur J Pediatr. 2003;162:697-702. doi:10.1007/ s00431-003-1276-x

7. Neumayr TM, Watson AM, Wylam ME, Ouellette Y. Surfactant treatment of an infant with acute idiopathic pulmonary hemorrhage. Pediatr Crit Care Med. 2008;9:e4-6. doi: 10.1097 /01.PCC.0000298755.86878.20

8. Suryawanshi P, Nagpal R, Meshram V, Malshe N, Kalrao V. Pulmonary hemorrhage $(\mathrm{PH})$ in extremely low birth weight (ELBW) infants: successful treatment with surfactant. J Clin Diagn Res. 2015;9(3):SD03-SD04. doi: 10.7860/ JCDR/ 2015/ 8596.5691

9. Rede Brasileira de Pesquisas Neonatais. Antenatal corticosteroid use and clinical evolution of preterm newborn infants. J Pediatr (Rio J). 2004;80:277-84.doi.org/10.1590/S0021-7557 2004000500006
10. Pandit PB, O’Brien K, Asztalos E, Colucci E, Dunn MS. Outcome following pulmonary haemorrhage in very low birth weight neonates treated with surfactant. Arch Dis Child Fetal Neonatal Ed. 1999;81:F40-4.doi: 10.1136/fn.81.1.F40

11. Bhandari V, Gagnon C, Rosenkrantz T, Hussain N. Pulmonary hemorrhage in neonates of early and late gestation. J Perinat Med. 1999;27:369-75.doi:10.1515/JPM.1999.050

12. West JB, Tsukimoto K, Mathieu-Costello O, Prediletto R. Stress failure in pulmonary capillaries. J Appl Physiol. 1991; 70:1731-42.doi: 10.1152/jappl.1991.70.4.1731

13. Chen YY, Wang HP, Lin SM, Chang JT, Hsieh KS, Huang $\mathrm{FK}$, et al. Pulmonary hemorrhage in very low-birthweight infants: risk factors and management. Pediatr Int. 2012;54(6): 743-7.doi: 10.1111/j.1442-200X.2012.03670.x

14. Strauss T, Rozenzweig N, Rosenberg N, Shenkman B, Livnat T, Morag I, et al. Surfactant impairs coagulation in-vitro: a risk factor for pulmonary hemorrhage? Thromb Res. 2013;132 (5):599-603.doi: 10.1016/j.thrombres.2013.09.001

15. Berger TM, Fontana M, Stocker M. The journey towards lung protective respiratory support in preterm neonates. Neonatology. 2013;104(4):265-74.doi: 10.1159/000354419

16. Vulic M, Lalic L, Vulic L, Roje D, Benzon Z, Mestrovic Z. A retrospective study of discordant twin growth in dichorionic twin pregnancies and risk of preterm delivery at Split University Hospital Centre: three-year experience. Acta Clin Croat. 2017;56:640-4. doi: 10.20471/acc.2017.56.04.09

Sažetak

\section{RANI ISHOD MASIVNOG PLUĆNOG KRVARENJA KOD NEDONOŠČADI U TUZLANSKOM KANTONU}

\section{Hadžić, E. Zulić, S. Salkanović-Delibegović, Dž. Softić, Dž. Kovačević i D. Softić}

Masivna plućna hemoragija (MPH) u novorođenčadi je teško stanje koje prati mnoštvo komplikacija i visoka stopa smrtnosti. Cilj ovoga istraživanja bio je utvrditi incidenciju, moguće čimbenike rizika i kratkoročni ishod neonatalne MPH u Tuzlanskom kantonu. Retrospektivno smo analizirali podatke o novorođenčadi s MPH od siječnja 2015. do prosinca 2017. godine. U statističkoj obradi primijenjene su standardne metode deskriptivne statistike.Tijekom promatranog trogodišnjeg razdoblja MPH se razvila u 16 novorođenčadi, 5 dječaka (31,25\%) dječaka i $11(68,75 \%)$ djevojčica. Srednja gestacijska dob

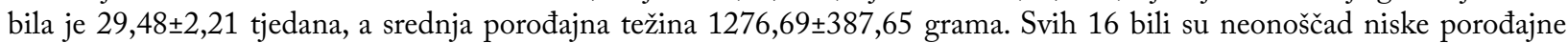
težine od kojih je $7(43,75 \%)$ preživjelo, a $9(56,25 \%)$ umrlo. Značajne razlike među dvjema skupinama ishoda nađene su za gestacijsku dob, porođajnu težinu, porođajnu duljinu, Apgar indeks u petoj minuti i dužinu intenzivnog liječenja. U zaključku, u Tuzlanskom kantonu neonatalna MPH javljala se kod nedonoččadi koja su zahtijevala mehaničku ventilaciju, s incidencijom od $1,91 \%$ od ukupnog broja prijevremeno rođenih. Kratkoročni ishod bio je neizvjestan, s visokom stopom smrtnosti od 56,25\%. Kraća gestacijska dob, niža porođajna težina, niža porođajna duljina i niži Apgar indeks u petoj minuti potvrđeni su kao čimbenici rizika za loš kratkoročni ishod.

Ključne riječi: Masivno plućno krvarenje; Nedonošč; Kratkoročni ishod; Čimbenici rizika 